\title{
Spermatozoa Morphology and Embryo Development of Four Species of Bivalves from Beibu Gulf
}

\author{
Jian Chen ${ }^{1,2,4, \#}$, Zhenghua Deng ${ }^{1,3,5, \#}$, Haijun Wei $^{1,3}$, Wang Zhao ${ }^{1,3}$, Mingqiang \\ Chen ${ }^{1,3}$, Gang $\mathrm{Yu}^{1}$, Jing Sun ${ }^{1,3}$, Dahui $\mathrm{Yu}^{2}$, Youning $\mathrm{Li}^{1,3}$, Yu Wang ${ }^{1,3, *} \mathbb{D}$, Lirong Bai ${ }^{2,4, *}$
}

\author{
${ }^{1}$ Key Laboratory of South China Sea Fishery Resources Development and Utilization, Ministry of Agriculture and Rural \\ Sciences, South China Sea Fisheries Research Institute, Chinese Academy of Fishery Sciences, Guangzhou Guangdong \\ 510300, PR China. \\ ${ }^{2}$ Guangxi Key Laboratory of Beibu Gulf Marine Biodiversity Conservation, Beibu Gulf University, Qinzhou Guangxi \\ 535011, PR China. \\ ${ }^{3}$ Sanya Tropical Fisheries Research Institute, Sanya Hainan 572018, PR China. \\ ${ }^{4}$ College of Animal Science and Technology, Guangxi University, Nanning Guangxi 530005, PR China. \\ ${ }^{5}$ Beihai Jinbuhuan Aquatic Products Co., Ltd., Beihai Guangxi 536007, PR China. \\ \#These authors contributed equally to this work.
}

\section{Article History}

Received 09 October 2020

Accepted 24 November 2020

First Online 25 November 2020

\section{Corresponding Author}

Tel.: +86089883361232

E-mail: winterrose@163.com, bailirong1152@163.com

\section{Keywords}

Beibu gulf

Economic bivalves

Spermatozoa morphology

Embryo development

\begin{abstract}
The morphology of sperm and early embryo development of shellfish can provide guidance for classification and biological reproduction. In this study, scanning electron microscopy and light microscopy were used to determine the shape of the sperm, characterize the embryonic development, and measured the size of the mature eggs and the D-shape larvae of four different clam species (Paphia schnelliana, Lutraria sieboldii, Antigona lamellaris, and Paphia textzle). The results showed that these four clam species differ in sperm morphology and the size of the mature eggs and the Dshape larvae $(P<0.01)$. There were also differences in embryonic development time and morphology. This analysis of spermatozoa morphology, egg size, D-shaped larvae size, and embryo development in these four different clam species provides the basis for classification and future breeding efforts.
\end{abstract}

\section{Introduction}

There are nearly 200 million acres of beaches in China, with extensive tidal flat shellfish breeding and cultivation of many types of shellfish that are sold fresh in seafood markets (Zhang, 2004). Paphia schnelliana, Antigona lamellaris, Paphia textzle, (Mollusca, Bivalvia, Heterodonta, Veneroida, Veneridae) and Lutraria sieboldii (Veneroida, Mactridae) are four clam species that are native to the Beibu Gulf of the South China Sea. These bivalves bore in sand or sand-mud and mainly live in intertidal zones and seabeds with sandy mud bottoms. Feeding on phytoplankton and organic detritus in the water, these clams have a short food chain and high ecological efficiency, so are called "herbivores" of the sea (Zhang et al., 2006). Tidal flat shellfish play an important role in the material cycle and energy flow of marine ecosystems, and can be used to detect environmental pollution. Additionally, clams have high economic value, are widely cultured, and are listed as key research and development species in China's "863" plan. In 2018, the annual output of mariculture clams in China was 4.08 million tons, making clams the second largest cultured shellfish species after oysters (Service, 2019). With delicious taste and short growth cycle, clams are highly suitable for artificial 
breeding. The efficient bottom sowing of these clams has enabled increasing cultivation in Beibu Gulf marine ranches and open aquaculture. Since the 1960s, researchers have studied the biology and breeding technology of clams, with significant advances in species identification (Zhang et al., 2012), phylogenetic analysis, and artificial seedling technology (Cheng et al., 2013). However, fertilization biology remains poorly understood for these four economically important clam species.

Characterization of fertilization biology is required for artificial reproduction and breeding efforts, including the structure of sperms and eggs and the overall fertilization process (Zhang et al., 2006; Dong et al., 2010). Differences in the morphological structure and size of shellfish gametes can serve as an important basis for the identification of shellfish species (Franzén, 1970; Franzén, 1977; Franzén, 1983b). The trochophore (Dshaped larva) stage is a critical period for the development of shellfish larvae, and the morphological characteristics and size of trochophores can also be used for species identification. For the family Veneridae, studies of sperm microstructure, submicroscopic structure, and embryonic development have mainly focused on Saxidomus purpurata (Kim, 2011), Meretrix meretrix (Dong et al., 2010), Cyclina sinensis (Zhu et al., 2008), Lucinacea (Johnson et al., 2015), Leptonacea (Eckelbarger et al., 1990), Mactracea (Longo and Anderson, 1969), Solenacea (Reunov and Hodgson, 1994), Tellinacea (Sousa et al., 1989; Hodgson et al., 1990; Reunov and Hodgson., 1994; Sousa and Oliveira., 1994), Corbiculacea (Konishi et al., 1998), Veneracea (Reunov and Hodgson., 1994), Ruditapes philippinarum (Ke et al., 2004), and Cyclina sinesis (Gmelin) (Shen et al., 2007). The results of these studies provide important information for species identification, reproductive evolution, fertilization mechanism, and cross breeding of shellfish. However, there have been few studies on the differences of bivalve eggs and hatchling larvae between species, limiting breeding efforts.

To gain insight into the fertilization biology of clams, this work focused on determination of the sperm and egg structure and analysis of embryo development of four common tidal flat species: $P$. schnelliana, $L$. sieboldii, A. lamellaris, and $P$. textzle. The results of this study expand our knowledge of the fertilization and developmental biology of Clamidae shellfish and can guide classification of Clamidae species and the identification of planktonic larvae. This work should provide the basis for future work to expand artificial propagation, breeding, and utilization of germplasm resources of clam family shellfish.

\section{Materials and Methods}

\section{Experimental Materials}

The four species (Table 1) used in the experiment were collected from wild populations in the Tieshan Port area of the Beihai Sea in Guangxi of China from November to December 2019. Healthy and complete clams were selected and transported to an incubation site at Beihai Jinbuhuan Aquatic Products Company for study.

\section{Artificial Insemination and Incubation}

At least 200 individuals of four populations of mudflat clams with mature gonads were randomly selected. The attachments outside the shells were removed, and phenotypic data were collected. Males and females were distinguished, and then artificial insemination was performed. Sperm and eggs were mixed in a $2 \mathrm{~L}$ beaker for activation, and then transferred to a $20 \mathrm{~L}$ incubator at a number ratio of 5:1 (sperm: eggs) to wait for fertilization. After 30 minutes, a 500-mesh screen was used to concentrate and filter out excess sperm. The material was then transferred to a 20 cubic hatching tank for incubation, and the embryo density was adjusted to $8 \sim 10$ individuals $\cdot \mathrm{mL}^{-1}$. The seawater used for fertilization and incubation was in the temperature range of $26.5^{\circ} \mathrm{C} 28.0^{\circ} \mathrm{C}$, with salinity of $32 \%$.

\section{Scanning Electron Microscopy}

After sperm were collected, they were filtered through a silk screen to obtain clean sperm and stored in in seawater at $\mathrm{pH} \quad 8.15-8.19$ with $4 \%$ paraformaldehyde. The preserved sperm washed in phosphate buffer, rinsed with distilled water, and then dehydrated with graded ethanol for observation (Turner and Boyle, 1974). After dehydration, samples were briefly placed in a chloroform solution and then allowed to dry in a steam environment of a sealed glass petri dish containing filter paper soaked in chloroform. Once dried, the samples were mounted on aluminum posts, coated with gold, and then subjected to a scanning electron microscopy Hitachi S 570.

\section{Observation of Embryo Development}

Samples of developing eggs were observed, and pictures were taken using a microscope (Phenix BMC536-ICCF) and a camera (ToupCam

Table 1. Statistics of four species parents shellfish phenotypes (mean \pm SD)

\begin{tabular}{lcccc}
\hline Species & Shell length $(\mathrm{mm})$ & Shell height $(\mathrm{mm})$ & Shell width $(\mathrm{mm})$ & Wet weight $(\mathrm{g})$ \\
\hline P. schnelliana & $69.81 \pm 4.02$ & $45.72 \pm 2.39$ & $28.43 \pm 1.67$ & $60.20 \pm 8.98$ \\
L. sieboldii & $73.21 \pm 2.64$ & $27.13 \pm 7.92$ & $36.68 \pm 1.37$ & $51.96 \pm 5.60$ \\
A. lamellaris & $53.60 \pm 1.84$ & $42.14 \pm 1.71$ & $32.75 \pm 1.54$ & $44.28 \pm 6.79$ \\
P. textzle & $58.29 \pm 2.62$ & $33.57 \pm 1.43$ & $20.81 \pm 0.95$ & $29.54 \pm 3.94$ \\
\hline
\end{tabular}


XCAM1080PHD). Egg diameter was measured with Image View 3.7 software (Phenix). From the fertilized egg, the embryos were imaged every 15 minutes during the first three hours of the embryonic development process. After three hours, samples were collected and photographed every half an hour to observe and record the development time for each stage.

\section{Results}

\section{Scanning Electron Microscopic Observation of Sperm}

All four species have primitive or the ectaquasperm form of sperm. The sperm had three parts: a head, a midpiece, and a flagellum, with the dimensions listed in Table 2. The head consists of a nucleus and acrosome, which is located at the front end of the head. The midpiece is located between the nucleus and caudal flagella and is composed of a complex of mitochondria and centrioles (Figure 1).

The longest sperm of $P$. schnelliana was about $50.16 \mu \mathrm{m}$, the middle of the head was thick, with a gyrolike shape and about $2.26 \mu \mathrm{m}$ long. The acrosome at the anterior end of the sperm is short, with an inverted conical shape. The ratio of head length to head width was 1.42. Four oval mitochondria were located in the middle part of sperm, with a small proportion of sperm head to total length, as shown in Figure 1-A.

The shortest sperm of L. sieboldii was $37.93 \mu \mathrm{m}$, with a dumbbell-shape head. The length was about 1.76 $\mu \mathrm{m}$, the acrosome was hemispherical, and the ratio of head length to head width was the smallest of the four species, 1.14, indicating a short and thick sperm head of $L$. sieboldii. Five spherical mitochondria were observed in the middle, as shown in Figure 1-B. The sperm length of $A$. lamellaris was about $41.48 \mu \mathrm{m}$, with a curvedcylinder head shape. The longest head was about 2.84 $\mu \mathrm{m}$. The middle segment consists of four flat mitochondria, as shown in Figure 1-C. The minimum ratio of tail length to head length was 13.45 . The total length of the sperm of $P$. textzle was $49.21 \mu \mathrm{m}$, and the long, cone-shaped head was 2.59 in length. The ratio of head length to head width is the largest for this species, with a value of 2.38 , indicating the slenderest sperm head of the tested species. The middle section contained four spherical mitochondria, as shown in Figure 1-D.

\section{Comparison of Embryonic Development}

With incubation in water of temperature $26.5 \sim 28.0$ ${ }^{\circ} \mathrm{C}$ and salinity $32 \%$, the immature eggs gradually changed from pear-shaped to ball-shaped, indicated the ability to be fertilized. After fertilization, the nucleus in the egg gradually disappeared, with the outer surface of the egg wrapped in a transparent egg membrane. Compared with the fertilized eggs of the other three species, the color of the fertilized eggs of $A$. lamellaris was darker and the diameter of the eggs was the largest.
The color of the fertilized eggs of $L$. sieboldii was lighter, and the shape of the fertilized eggs was rounder and smaller than that of the Paphian clam, as shown in Figure 2, 3, 4 and 5. The times required for development of the fertilized egg to the discharge of the first polar body were 5 minutes for $P$. schnelliana, 20 minutes for A. lamellaris, and 10 minutes for both $P$. textzle and $L$. sieboldii. The second polar body was discharged within minutes after discharge of the first polar body. The fertilized eggs consisted of two different size division spheres, with the whole body of the embryo in the shape of gourd. A total of 19 minutes was required for development to the first cleavage for $L$. sieboldii, the fastest of the four species, and 35 minutes was required for this step for A. lamellaris, the slowest of the four species. After about three hours of development, the zygotes of these bivalves developed into a morula stage, and numerous spherical cells gathered into clusters with obvious layers. Cilia began to grow on the outer surface, allowing autonomous swimming. After an hour, the surface roughness of embryo gradually weakened, the number of cilia increased, and the activity speed increased obviously, as shown in Table 3.

During development to the trochophore stage, the gyro-shaped embryo had thick cilia on the surface. The time for larvae development can vary for different shellfish, with trochophore stage development times for the four species of $6 \mathrm{~h} 15 \mathrm{~min}$ for $L$. sieboldii, $8 \mathrm{~h}$ for $P$. textzle, $10 \mathrm{~h} 47 \mathrm{~min}$ for $P$. schnelliana, and $11 \mathrm{~h}$ for $A$. lamellaris.

The embryos continued to develop, and the upper anterior ciliary rings gradually developed into velum, forming a straight line on one side. On the other side, the velum of the adjacent development began to arc, and the larvae gradually flattened. The linear part eventually developed into the " $D$ " form of the hinge of larval shells, and both sides grew into two-disc shapes. The D-shaped larval stage is also called the veliger stage. The digestive tract starts to mature in this stage and the body yolk is gradually exhausted, so the two ciliated flaps are used for swimming and feeding. At a temperature of $27.0^{\circ} \mathrm{C}$ and salinity of $32 \%$, the times required for the four species of shellfish to develop from fertilized egg to self-swimming D-shaped floating larvae were $16 \mathrm{~h} 10 \mathrm{~min}$ for $P$. schnelliana, $16 \mathrm{~h} 50 \mathrm{~min}$ for $P$. textzle, $19 \mathrm{~h} 09 \mathrm{~min}$ for L. sieboldii, and $22 \mathrm{~h} 10 \mathrm{~min}$ for A. lamellaris.

\section{Comparison of Egg Size and D-Shape Larvae Size}

The size of eggs and D-shape larvae for $P$. schnelliana, L. sieboldii, A. lamellaris, and P. textzle were next determined and the results are shown in Figure 6. Eggs that were round when placed for 10 minutes in seawater were considered mature eggs and were measured. The mean diameters of mature eggs (Figure 6-A) of $P$. schnelliana, L. sieboldii, A. lamellaris, and $P$. textzle were $70.35 \pm 1.41 \mu \mathrm{m}, 54.15 \pm 0.88 \mu \mathrm{m}, 68.15 \pm$ $2.65 \mu \mathrm{m}$, and $56.93 \pm 1.52 \mu \mathrm{m}$, respectively; the shell 
Table 2. Sizes of sperm from four species of bivalve. (mean \pm SD)

\begin{tabular}{|c|c|c|c|c|c|c|c|}
\hline \multirow{2}{*}{ Species } & \multirow{2}{*}{ Total length $(\mu \mathrm{m})$} & \multicolumn{2}{|c|}{ Head $(\mu \mathrm{m})$} & \multirow{2}{*}{$\begin{array}{l}\text { L/W } \\
\text { ratio }\end{array}$} & \multirow{2}{*}{$\begin{array}{c}\text { Tail }(\mu \mathrm{m}) \\
\text { Length } \\
\end{array}$} & \multirow{2}{*}{$\mathrm{T} / \mathrm{H}$ ratio } & \multirow{2}{*}{$\begin{array}{c}\text { Mitochondria } \\
\text { number }\end{array}$} \\
\hline & & Length & Width & & & & \\
\hline P. schnelliana & $50.16 \pm 7.26^{a}$ & 2.26 & 1.59 & 1.42 & 47.37 & 17.00 & 4 \\
\hline L. sieboldii & $37.93 \pm 5.03^{c}$ & 1.76 & 1.55 & 1.14 & 35.38 & 13.87 & 5 \\
\hline A. lamellaris & $41.48 \pm 3.05^{b}$ & 2.84 & 1.26 & 2.25 & 38.19 & 11.63 & 4 \\
\hline P. textzle & $49.21 \pm 4.54^{a}$ & 2.59 & 1.09 & 2.38 & 45.95 & 14.07 & 4 \\
\hline
\end{tabular}

Note: "L" means length, "W" means width, " $\mathrm{T}$ " means tail, " $\mathrm{H}$ " means head. Different letters in the same column indicate significant differences $(P<0.05)$.

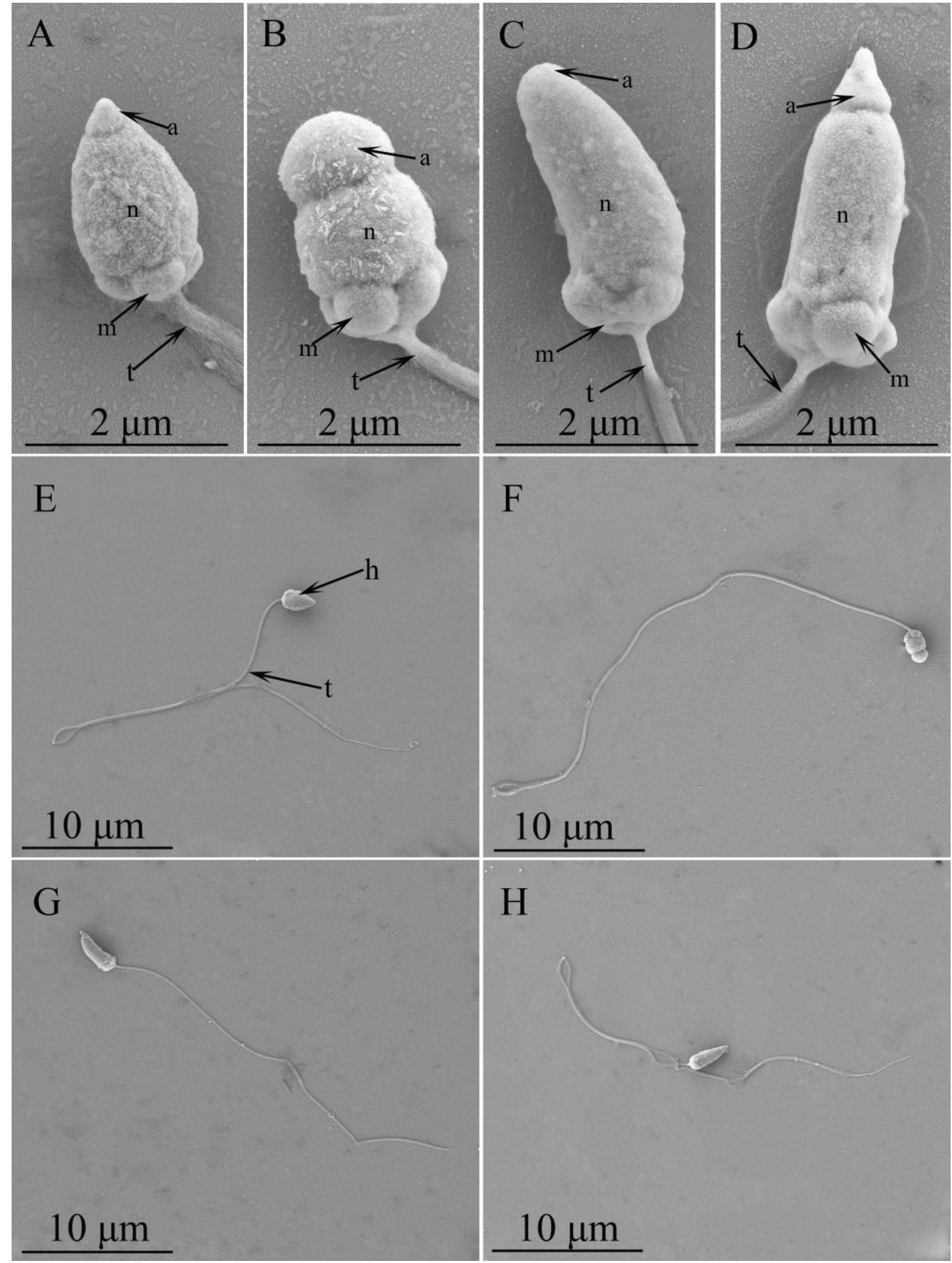

Figure 1. Scanning electron micrographs of the sperm of four species shellfish; A, and E. Paphia schnelliana; B, and F. Lutraria sieboldii; C, and G. Antigona lamellaris; D, and H. Paphia textzle); a. acrosomal granule; m. mitochondrion; $\mathrm{n}$. nucleus; $\mathrm{h}$. head; $\mathrm{t}$. tail. 


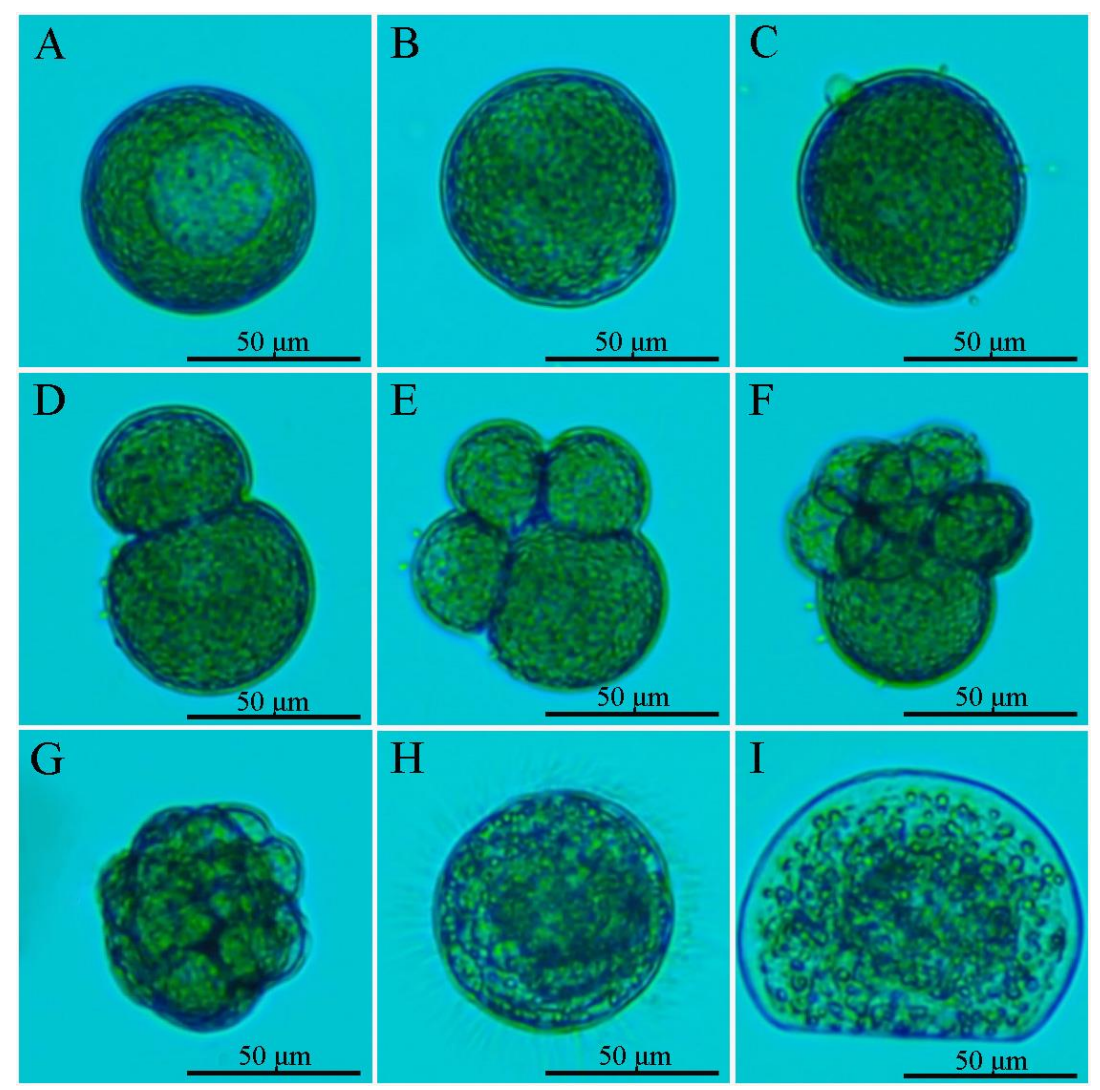

Figure 2. Morphological changes in embryonic development of $P$. schnelliana; A. Egg; B. the fertilized egg; C. First polar body; D. 2cell stage; E. 4-cell stage; F. 8-cell stage; G. lastula; H. Trochophore; H. D-shape larva. The same below

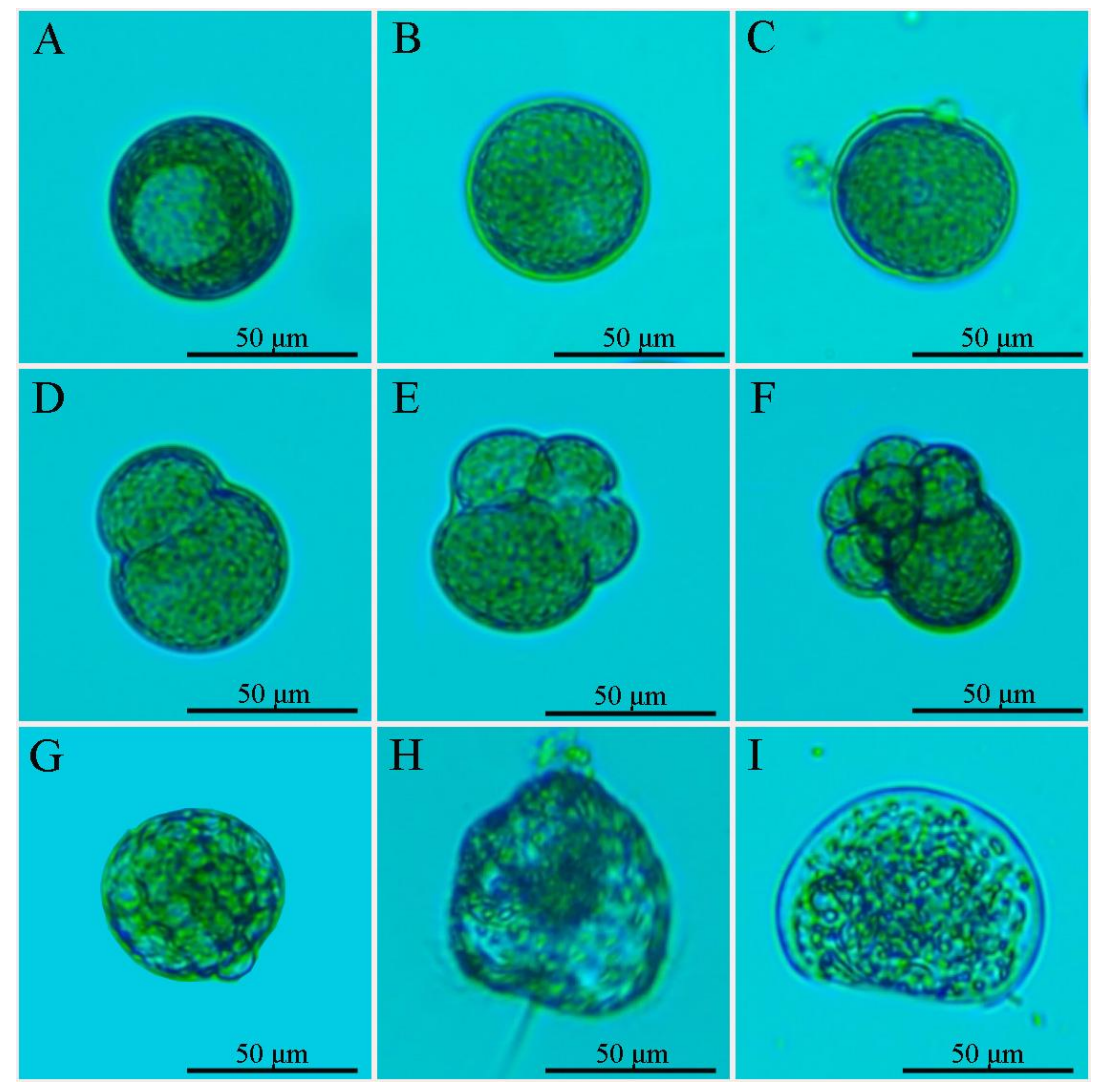

Figure 3. Morphological changes in embryonic development of L. sieboldii; A. Egg; B. the fertilized egg; C. First polar body; D. 2-cell stage; E. 4-cell stage; F. 8-cell stage; G. lastula; H. Trochophore; H. D-shape larva. 


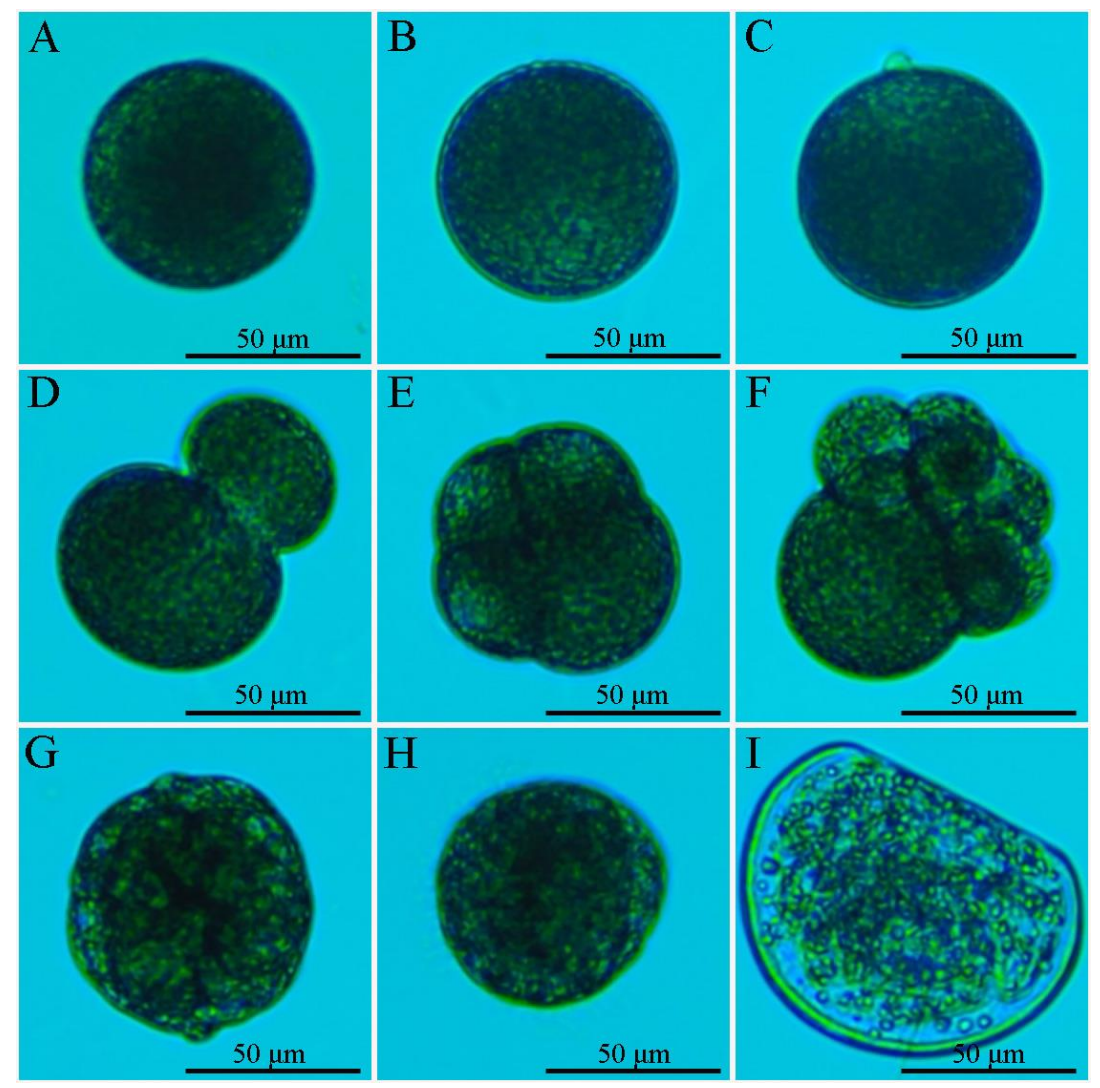

Figure 4. Morphological changes in embryonic development of $A$. lamellaris; A. Egg; B. the fertilized egg; C. First polar body; D. 2-cell stage; E. 4-cell stage; F. 8-cell stage; G. lastula; H. Trochophore; H. D-shape larva. The same below

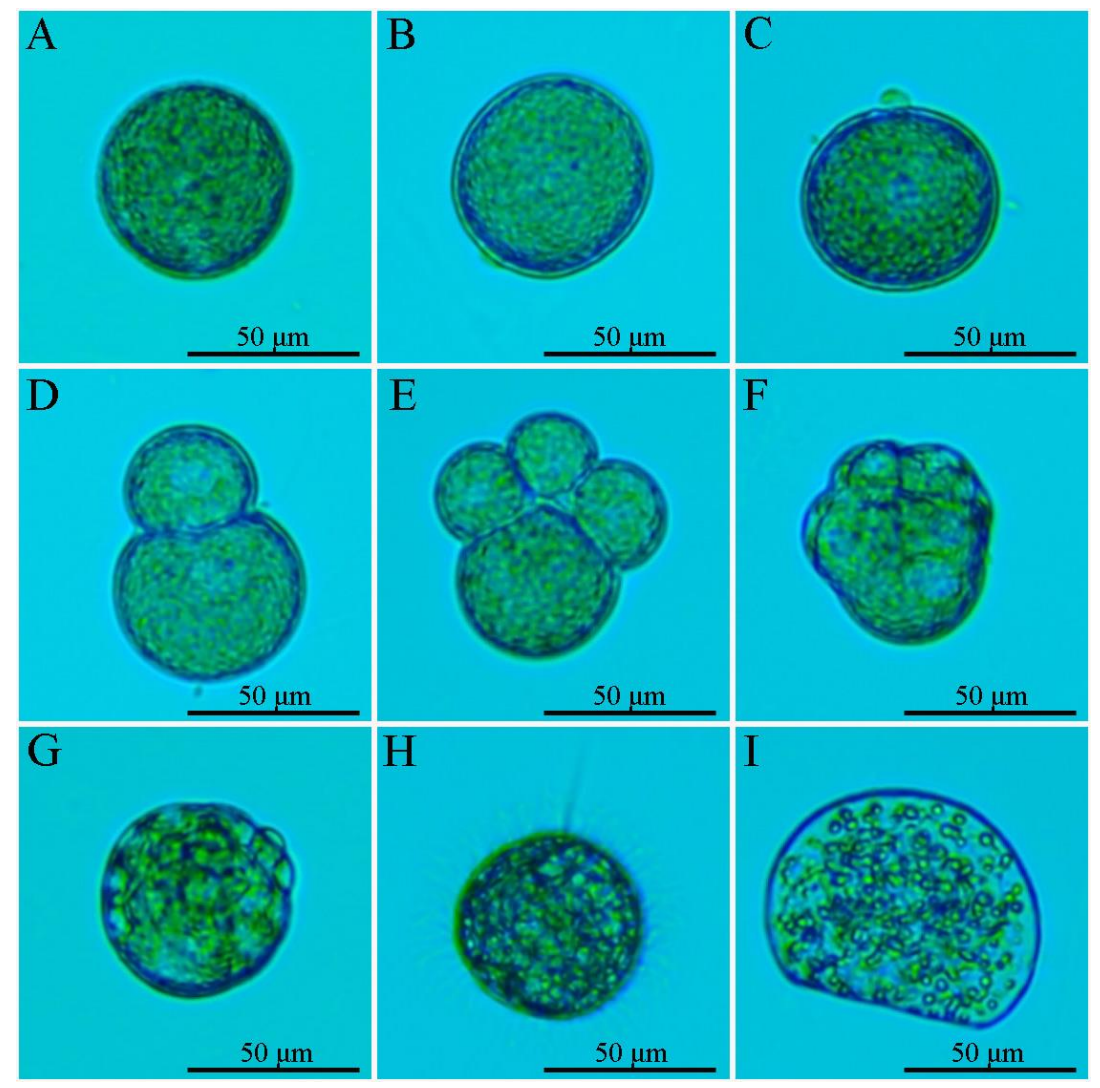

Figure 5. Morphological changes in embryonic development of P. textzle; A. Egg; B. the fertilized egg; C. First polar body; D. 2-cell stage; E. 4-cell stage; F. 8-cell stage; G. lastula; H. Trochophore; H. D-shape larva. 
Turk. J. Fish.\& Aquat. Sci. 21(2), 51-61

Table 3. Development timeable of embryos of four species shellfish (T: $26.5^{\sim} 28.0^{\circ} \mathrm{C}$; S: $32 \%$ )

\begin{tabular}{lccc}
\hline Stages & P. schnelliana & L. sieboldii & A. lamellaris \\
\hline Fertilized egg & $0: 00$ & $0: 00$ & $0: 00$ \\
First polar body & $0: 05$ & $0: 10$ & $0: 20$ \\
2-cell stage & $0: 20$ & $0: 19$ & $0: 35$ \\
4-cell stage & $0: 33$ & $0: 44$ & $0: 56$ \\
8-cell stage & $0: 47$ & $1: 18$ & $1: 26$ \\
16-cell stage & $1: 20$ & $1: 42$ & $1: 40$ \\
32-cell stage & $2: 29$ & $2: 18$ & $2: 30$ \\
Morula & $3: 22$ & $2: 43$ & $2: 54$ \\
Blastula & $4: 25$ & $3: 22$ & $4: 40$ \\
Gastrulae & $6: 25$ & $3: 58$ & $8: 00$ \\
Trochophore & $10: 47$ & $6: 15$ & $2: 23$ \\
D-larvae stage & $16: 10$ & $19: 09$ & $3: 17$ \\
\hline
\end{tabular}
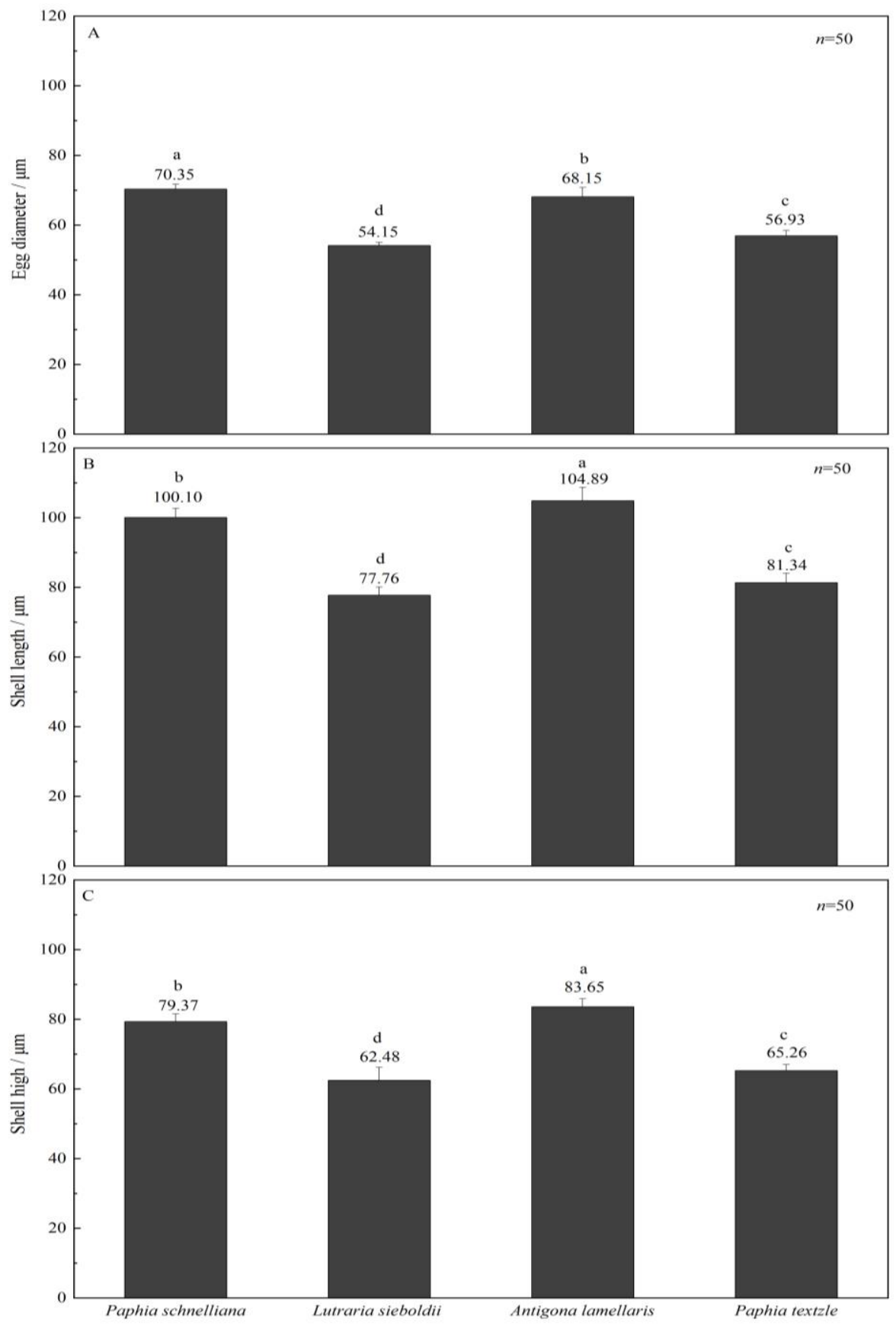

Four kinds of shellfish

Figure 6. The diameter of the mature eggs and shell lentgth, shell width of D-shape larva of the four shellfish; different superscripts identify defferents $(P<0.05)$ 
lengths (Figure 6-B) of the D-shape larvae were $100.10 \pm$ $2.61 \mu \mathrm{m}, 77.76 \pm 2.29 \mu \mathrm{m}, 104.89 \pm 3.88 \mu \mathrm{m}$, and 81.34 $\pm 2.73 \mu \mathrm{m}$, respectively; and the shell heights (Figure 6C) were $79.37 \pm 2.16 \mu \mathrm{m}, 62.48 \pm 3.76 \mu \mathrm{m}, 83.65 \pm 2.22$ $\mu \mathrm{m}, 65.26 \pm 1.73 \mu \mathrm{m}$, respectively. There were significant differences $(P<0.01)$ in the egg diameter and $D$-shaped larva size of the four kinds of clams. The clams in order of largest to smallest egg diameters are $P$. schnelliana, A. lamellaris, P. textzle, and L. sieboldii. There was no significant correlation between the size of the initial hatching veliger and egg diameter, but the shell height and shell length of the initial hatching veliger were correlated, and the larger the shell height of the larva, the larger the shell length. The clams in order of largest shell height and length to the smallest are A. lamellaris, $P$. schnelliana, $P$. textzle, and $L$. sieboldii.

\section{Discussion}

The four clam species studied ( $P$. schnelliana, $L$. sieboldii, A. lamellaris, and $P$. textzle) are endemic to the Beibu Gulf and have high economic value. These species grow in the same areas, and our study helps to distinguish these species at the larval stage. There are three main types of mature sperm of invertebrates: aquasperm (ect-aquasperm and ent-aquasperm), introsperm, and dimorphic or polymorphic sperm. Ectaquasperm are primitive and shed in water, where they can fertilize (Jamieson., 1987; Rouse and Jamieson., 1987). Ect-aquasperm have a small head containing a rounded or conical nucleus that is surrounded by a cupshaped acrosomal vesicle, a midpiece with a ring of $4 \sim 5$ rounded mitochondria encircling two centrioles, and a tail flagellum that is about $50 \mu \mathrm{m}$ long (Franzén, 1983b; Gwo et al., 2002; John et al., 2015; CamachoMondragon et al., 2014; Campos et al., 2018). Here, the spermatozoa of all four species were analyzed and found to be ect-aquasperm. These species utilize in vitro fertilization, with the expulsion of mature sperm and eggs from the body to the water for the completion of fertilization (Franzén, 1977; Barnes, 1980).

Spermatozoa from several bivalves have been studied by electron microscopy, e.g., Crassostrea virginica (Daniels et al., 1971); Musculus discors, Nucula sulcata, and Dreissena polymorpha (Franzén, 1983a); Arcidae (Anadara broughtonii and Arca boucardi), Anomiidae (Pododesmus macrochisma), Tellinidae (Macoma tokyoensis), Myidae (Mya japonica), and Trapezidae (Trapezium liratum) (Drozdov et al., 2009); Gafrarium tumidum, Circe scripta (Circinae), Pitar sulfureum (Pitarinae), and Gomphina aequilatera (Tapetinae) (Gwo et al., 2002); Spisula solidissima (Longo, 2010); Bankia australis and Bankia carinata (Popham, 1974); Laternula limicola (Kubo and Miyoko, 1977); Lyonsia ventricosa (Kubo, 1978); and Barnea candida (Pasteels and Harven, 1962).

Morphological and morphometric parameters of spermatozoa are useful biomarkers (Figueroa et al.,
2016). Head length, midpiece length, and flagellum length of sperm are considered the most important morphological parameters, since these characteristics are not only closely related to movement mode and fertilization process, but also reflect the reproductive evolutionary status of species, allowing for animal classification (Dong et al., 2010; Tichopád et al., 2020). In this study, the morphology and size ratio of sperm of four bivalves were compared. The sperm showed some differences but all maintained some morphological similarity to sperm of Cyclina sineusis (Gao et al., 2007), Meretrix meretrix (Dong et al., 2010), Mercenaria mercenaria (Ying et al., 2008), Antigona lamellaris, and Saxidomus purpurata (Kim, 2011), with slightly curved cylindrical sperm heads. However, there are some differences in sperm length, tail length to head length ratio, head length to width ratio, and other parameters, allowing species identification. Differences in size can also reflect the nearness of genetic relationships. For example, Erkan et al. (2002) compared the ultrastructure of sperm of Pitar Rudis and Chamelea Gallina of the family Veneridae and found that acrosome morphology could be used as the basis for inter-specific differentiation. Gwo et al. (2002) compared the spermatozoa morphology of four mussels of the family Cerasus subtilis and found that acrosome shape and the size of the nucleus of spermatozoa distinguished the four species. Introíni et al. (2009) studied the ultrastructure of sperm of Isognomon bicolor and Isognomon Alatus, finding that the morphological and structural differences of sperm can facilitate taxonomic differentiation of shellfish.

Egg characteristics are important reproductive characteristics and provide an important representation of the spawning environment (Li et al., 2015). The initial hatchling surface dish larva (D-shaped larva) stage is a key stage in the development of planktic larva of shellfish. The classification of Corydalaceae is progressing slowly, with few defined characteristics to aid in classification. To provide reference for classification and genetic breeding, this study compared the size of eggs and larvae (D-shaped larvae) of four clam species commonly found in the Beibu Gulf. The size of eggs is an important biological parameter of reproductive characteristics, and an important representation of the spawning environment (Li et al., 2015). Egg size is correlated with survival rate, fertilization rate, and embryonic development (You et al., 2010; Pan et al., 2011). Egg size and microstructure can help species classification (Yang et al., 1995). Xu et al. (2009) measured and analyzed the shell height and shell length of larvae on the first hatching surface of seven common oysters, and found that the shell height and shell length of larvae were highly correlated, and that the size of oyster larvae during early hatching can be used to distinguish species. In this study, the size of eggs and larvae were determined for four species of clams native to the Beibu Gulf waters, allowing the identification of larvae in the plankton-stage. 
Characterization of the morphology and timing of the embryonic development process of shellfish can provide reference for artificial breeding of shellfish (Wu et al., 2017). The first polar body was released in the first 20 minutes after fertilization by the fertilized eggs of $P$. schnelliana, L. sieboldii Reeve, $A$. lamellaris, and $P$. textzle, timing that was consistent with that reported in previous studies of other shellfish in the family Veneridae (Wu et al., 2017) and Ruditapes philippinarum (Ke et al., 2004). At $26^{\sim} 28^{\circ} \mathrm{C}$ temperature and salinity of $31-32 \%$, the development times of $P$. schnelliana and $A$. lamellaris were close to that of the Trochophore and D-shaped larva stage, which lasted for more than $16 \mathrm{~h}$. This development time is close to that of Meretrix lyrata (Li et al., 2015) at $28^{\sim} 30^{\circ} \mathrm{C}$ and Cyclina sinesis (Shen et al., 2007) at $28^{\circ} \mathrm{C}$. The early embryo development of $P$. schnelliana was rapid, with opening for food $20 \mathrm{~h}$ after fertilization. However, the development of $A$. lamellaris is relatively slow, with 22 hours required to develop from zygote to D-shaped larva.

\section{Conclusions}

Spermatozoa morphology and embryo development were studied in four different species of beach clams. Differences in the morphology of sperm and the size of the mature eggs and the D-shape larvae can facilitate the classification of $P$. schnelliana, $L$. sieboldii, A. lamellaris, and $P$. textzle. There were significant differences $(P<0.01)$ in the size of the mature eggs and the D-shape larvae for the different species. The embryonic development time and morphology also differed.

\section{Acknowledgement}

This study was funded and supported by the Central Public-interest Scientific Institution Basal Research Fund, South China Sea Fisheries Research Institute, CAFS (2019TS07), National Key R\&D Program of China (2019YFD0900905), Financial Fund of Ministry of Agriculture and Rural affairs of China (NHYYSWZZZYKZX2020), Special Funds for the Construction of Modern Agricultural Industry Technology System (CARS-49) .

\section{References}

Camacho-Mondragon, M.A., Ceballos-Vazquez, B.P., Galicia, E.U., Villegas, E.O.L., \& Arellano-Martinez, M. (2014). Ultrastructure of the Spermatogenic Process in the Penshell Atrina maura (Bivalvia: Pinnidae). Malacologia. 57(2), 329-339. https://doi.org/10.4002/040.057.0206

Campos, A., Introíni, G.O., Tallarico, L.d.F., Passos, F.D., Machado, F.M., \& Recco-Pimentel, S.M. (2018). Ultrastructure of the spermatozoa of three species of Anomalodesmata (Mollusca, Bivalvia) and phylogenetic implications. Acta Zoologica. 101(2), 156-166. https://doi.org/10.1111/azo.12282
Cheng, H., Peng, Y., Dong, Z., Yi, L., \& Chen, D. (2013). Phylogenetic analysis of Veneridae (Mollusca: Bivalvia) based on the mitochondrial cytochrome coxidase subunit I gene fragment. Acta Ecologica Sinica. 33, 27442753. https://doi.org/10.5846/stxb201202030140

Barnes, R.D. (1980). Invertebrate zoology. 4th ed. Bioscience. 12, 362-486. https://doi.org/10.2307/1294886

Daniels, E.W., Longwell, A.C., McNiff, J.M., \& Wolfgang, R.W. (1971). Ultrastructure of Spermatozoa from the American Oyster Crassostrea virginica. Transactions of the American Microscopical Society. 90, 275-282. https://doi.org/10.2307/3225187

Dong, Y.H., Lin, Z.H., Chai, X.L., \& Song-Yan, W.U. (2010). Electron microscope observation on ultrastructure of spermatozoon and penetration in meretrix meretrix. Oceanologia Et Limnologia Sinica. 41, 726-732. https://doi.org/10.3724/SP.J.1011.2010.01138

Drozdov, A.L., Sharina, S.N., \& Tyurin, S.A. (2009). Sperm ultrastructure in representatives of six bivalve families from Peter the Great Bay, Sea of Japan. Russian Journal of Marine Biology. 35, 236-241. https://doi.org/10.1134/\$1063074009030079

Eckelbarger, K.J., Bieler, R., \& Mikkelsen, P.M. (1990). Ultrastructure of sperm development and mature sperm morphology in three species of commensal bivalves (Mollusca: Galeommatoidea). Journal of Morphology. 205, 63-75. https://doi.org/10.1002/jmor.1052050107

Erkan, M., \& Sousa, M. (2002). Fine structural study of the spermatogenic cycle in Pitar rudis and Chamelea gallina (Mollusca, Bivalvia, Veneridae). Tissue \& Cell. 34, 262272. https://doi.org/10.1016/S0040-8166(02)00016-2

Figueroa, E., Valdebenito, I., \& Farias, J.G. (2016). Technologies used in the study of sperm function in cryopreserved fish spermatozoa. Aquaculture Research. 47, 1691-1705. https://doi.org/10.1111/are.12630

Franzén, A. (1977). Sperm structure with regard to fertilization biology and phylogenetics. Verh. Dtsch. Zool. Ges. 1977, 123-138.

Franzén, A. (1983a). Ultrastructural studies of spermatozoa in three bivalve species with notes on evolution of elongated sperm nucleus in primitive spermatozoa. Gamete Research. 7, 199-214. https://doi.org/10.1002/mrd.1120070302

Franzén, ̊̊. (1970). Phylogenetic aspects of the morphology of spermatozoa and spermatogenesis. Comparative spermatology. Academic Press. 29-46.

Franzén, k. (1983b). Ultrastructural studies of spermatozoa in three bivalve species with notes on evolution of elongated sperm nucleus in primitive spermatozoa. Gamete Research. 7, 199-214. https://doi.org/10.1002/mrd.1120070302

Gao, Y.M., Bai, H.M.J.L.T., \& Sun, J.X. (2007). Ultrastructure of Spermatozoon in Cyclina sineusis. Fisheries Science. 26, 95-98.

Gwo, J.C., Yang, W.T., Sheu, Y.T., \& Cheng, H.Y. (2002). Spermatozoan morphology of four species of bivalve (Heterodonta, Veneridae) from Taiwan. Tissue \& Cell. 34, 39-43. https://doi.org/10.1054/tice.2002.0222

Hodgson, A.N., Bernard, R.T.F., \& Vanderhorst, G. (1990). Comparative spermatology of three species of Donax (bivalvia) from south Africa. Journal of Molluscan Studies. 257-265. https://doi.org/10.1093/mollus/56.2.257

Introíni, G.O., Magalhães, C.A., Fortunato, H., \& ReccoPimentel, S.M. (2009). Comparison of the spermatozoan 
morphology of Isognomon bicolor and Isognomon alatus (Mollusca, Bivalvia, Isognomonidae). Tissue \& Cell. 41, 074. https://doi.org/10.1016/j.tice.2008.07.002

Jamieson, B.G.M. (1987b). A biological classification of sperm types, with special reference to annelids and molluscs, and an example of spermiocladistics. Japan Scientific Society Press, Tokyo/Gordon \& Breach Science Publishers, New York, 311-332.

John, M., Healy, Paula, M., \& Mikkelsen, Rüdiger, Bieler. (2015). Spermatogenic ultrastructure in the anomalodesmatan bivalve Myochama anomioides (Mollusca: Myochamidae) - does the nucleus help position the 'temporary' acrosome? Acta Zoologica. 96, 487-496. https://doi.org/10.1111/azo.12093

Johnson, M.J., Casse, N., \& Pennec, M.L. (2015). Spermatogenesis in the endosymbiont - bearing bivalve Loripes lucinalis (Veneroida: Lucinidae). Molecular Reproduction and Development. 45, 476-484. https://doi.org/10.1002/(SICI)10982795(199612)45:4<476:AID-MRD10>3.0.CO;2-V

Ke, B.I., Bao, Z.M., Huang, X.T., Wang, J., Fang, J.G., \& Hui, L. (2004). Cytological observations on fertilization and early embryonic development in Ruditapes philippinarum. Journal of Fisheries of China. 28, 623-627. https://doi.org/10.1007/BF02873091

Kim, J.H. (2011). Spermiogenesis and taxonomic value of sperm morphologies of two species in Veneridae (Bivalvia: Heterodonta). The Korean Journal of Malacology. 27, 149-157. https://doi.org/10.9710/kjm.2011.27.2.149

Konishi, K., Kawamura, K., Furuita, H., \& Komaru, A. (1998). Spermatogenesis of the freshwater clam Corbiculaaff. Fluminea muller (Bivalvia: Corbiculidae). Journal of Shellfish Research, 17(1), 185-189.

Kubo, Miyoko. (1977). The formation of a temporary acrosome in the spermatozoon of Laternula limicola (Bivalvia, Mollusca). Journal of Ultrastructure Research, 61(1), 140-148. https://doi.org/10.1016/S0022-5320(77)90013-2

Kubo, M., \& Ishikawa, M. (1978). Organizing process of the temporary acrosome in spermatogenesis of the bivalve Lyonsia ventricosa. Submicrosc Cytol. 10, 411-421.

Li, Z.M., Qian, J.H., Liu, Z.G., Liu, J.S., \& Yan, H. (2015). Development of embryo, larvae and spat of Meretrix lyrata. Marine Sciences. 39, 52-59.

Longo, F.J., \& Anderson, E. (1969). Spermiogenesis in the surf clam Spisula solidissima with special reference to the formation of the acrosomal vesicle. Journal of Ultrastructure Research. 27, 435-443. https://doi.org/10.1016/S0022-5320(69)80042-0

Longo, F.J. (2010). An ultrastructural analysis of polyspermy in the surf clam, Journal of Experimental Zoology Part A Ecological Genetics \& Physiology, 183(2), 153-180.

Pan, X.F., Yang, J.X., Chen, X.Y., \& Li, Z.Y. (2011). Broodstocks management, fecundity and the relationship between egg size and embryo survival ability of Sinocyclocheilus grahami. Zoological Research. 32, 196. https://doi.org/10.3724/SP.J.1141.2011.02196

Pasteels, J., \& J. Harven, E. De. (1962). Étude au microscope électronique de spermatozoïde d'un mollusque bivalve, Barnea Candida. Arch. Biol. (Liège). 73, 445-463.

Popham, J.D. (1974). Comparative morphometrics of the acrosomes of the sperms of "externally" and "internally" fertilizing sperms of the shipworms (Teredinidae,
Bivalvia, Mollusca). Cell Tissue Research. 150, 291-297. https://doi.org/10.1007/BF00220138

Reunov, A.A., \& Hodgson, A.N. (1994). Ultrastructure of the spermatozoa of five species of South African bivalves (Mollusca), and an examination of early spermatogenesis. J Morphol. 219, 275-283. https://doi.org/10.1002/jmor.1052190307

Rouse, G.W., \& Jamieson, B.G.M. (1987). An ultrastructural study of the spermatozoa of the polychaetes Eurythoe complanata (Amphinomidae), Clymenella sp. and Micromaldane $s p$. (Maldanidae). With a definition of sperm types in relation to reproductive biology. Journal of Submicroscopic Cytology \& Pathology. 19, 573-584. https://doi.org/10.1002/path.1711530214

Service, D.o.A.F. (2019). China fishery statistical yearbook. China Agriculture Press. 19-23.

Shen, B., Sun, Y., \& Yu, Y. (2007). Biology of embryonic development of Cyclina sinesis (Gmelin). Modern Fisheries Information. 22, 28-30.

Sousa, M., Corral, L., \& Azevedo, C. (1989). Ultrastructural and cytochemical study of spermatogenesis in Scrobicularia plana (Mollusca, Bivalvia). Gamete Research. 24, 393. https://doi.org/10.1002/mrd.1120240406

Sousa, M., \& Oliveira, E. (1994). Ultrastructural and cytochemical study of spermatogenesis in Donax trunculus (Mollusca, Bivalvia). Journal of Submicroscopic Cytology \& Pathology. 26, 305-311.

Tichopád, T., Vetešník, L., Šimková, A., Rodina, M., Franěk, R., \& Pšenička, M. (2020). Spermatozoa morphology and reproductive potential in $\mathrm{F} 1$ hybrids of common carp (Cyprinus carpio) and gibel carp (Carassius gibelio). Aquaculture. 521, 735092.

https://doi.org/10.1016/j.aquaculture.2014.10.021

Turner, R.D, \& Boyle, P.J. (1974). Studies of bivalve larvae using the scanning electron microscope and critical point drying. Bulletin of the American Malacological Union, Inc. 40, 59-65.

Wu, Q.S., Wen, Y., Zeng, Z.N., Wang, X.Q., Ning, Y., Qi. J.F., Luo, J., \& Jia, Y.Y. (2017). The reproductive cycle and embryonic development of the bivalve mollusk Tapes conspersus. Journal of Fishery Sciences of China. 24, 488496.

Xu, F., Li, L., \& Zhang, G.F. (2009). Comparison of the size of the first hatching larvae of oysters in China, The 14th Symposium of zoology society of China and shellfish society branch of China Ocean and Limnology Society. 6 8.

Yang, D.L., Ji, X.R., Cha, H.F., \& Chang, M.J. (1995). Study on the ultrastruture of the chorion from marine fishes. Study marian sinica. 36, 217-221.

Ying, X.P., Yang, W.X., Dahms, H.U., Lin, Z., \& Chai, X. (2008). Spermatozoa and spermatogenesis in the northern quahaug Mercenaria mercenaria (Mollusca, Bivalvia). Helgoland Marine Research. 62, 321-329. https://doi.org/10.1007/s10152-008-0119-6

You, K.M., Ma, C.H., Wang, S.J., Gao, T.X., Fan, Z.L., \& Wan, Q.Y. (2010). The preliminary study of egg diameter and fertilization ability of jellyfish, Rhopolema Esculentum Kishinouye. Transactions of Oceanology and Limnology. 10, 56-60. https://doi.org/10.3724/SP.J.1238.2010.00453

Zhang, G.F. (2004). Considerations on the development of healthy mudflat culture. Bulletin of the Chinese Academy of Sciences. 19, 442-445. 
Zhang, S., Wang, H., \& Xu, F. (2012). Taxonomic study on meretrix (Bivalvia, Veneridae) from China seas. Zoological Systematics. 37, 473-479.

Zhang, Y.H., \& Chen, B. (2006). Research progress on ultrastructure and ontogeny of sperm and egg in common beach shellfish. Sciencepaper Onine. 2, 1-7.
Zhu, J.Q., Ding, L.F., Shen, H.D., Xu, S.J., \& Ye, T. (2008). Spermatozoa morphology and effects of environmental factors on spermatozoa motility in Cyclina sinensis. Journal of Shanghai Fisheries University. 17, 547-552. https://doi.org/10.3724/SP.J.1035.2008.00038 